\title{
Will Academics Drive or Obstruct the Slovenian Government's Internationalisation Agenda for Higher Education?
}

\section{Alenka Flander $^{\star 1}$ And Manja KlemenČič²}

$\approx$ The present article is concerned with the question of how conducive the academic culture and climate in Slovenian higher education institutions are to internationalisation. Our underlying assumption is that academic staff represent either an important driving force or an obstacle to the implementation of internationalisation policies formulated at the national level and diffused into institutional practices. Specifically, we investigate whether the present academic attitudes and behaviours are in line with the internationalisation aims and objectives stated in the National Higher Education Programme 2011-2020. Our findings point to generally favourable attitudes of academics towards internationalisation. We also find that academics' own priorities regarding internationalisation tend to be higher than the perceived priorities of their respective institutions. At the same time, however, the preferences of academics regarding the various activities associated with the "internationalisation of study at home", especially conducting courses in foreign languages, are lower and highly divergent, and might therefore obstruct the government's agenda in this regard.

Keywords: the academic profession, academic culture, higher education reforms, Slovenia, internationalisation, international cooperation, the internationalisation of study at home 


\section{Bodo visokošolski učitelji podprli ali zavrli načrt slovenske vlade o internacionalizaciji visokega šolstva?}

Alenka Flander $^{*}$ And Manja Klemenčič

$\propto$ V prispevku ugotavljamo, koliko sta akademska kultura in klima v slovenskih visokošolskih ustanovah naklonjeni internacionalizaciji. Avtorici predpostavljata, da so zaposleni v visokem šolstvu pomembno gonilo ali pa ovira za implementacijo internacionalizacijske politike, oblikovane na državni ravni in razširjene v praksah ustanov. Še posebej ugotavljata, ali so trenutne akademske naravnanosti in ravnanja v skladu s cilji in $\mathrm{z}$ nameni internacionalizacije, kot jih navaja Nacionalni program visokega šolstva 2011-2020. Njuni rezultati kažejo, da so akademiki na splošno naklonjeni internacionalizaciji. Ugotavljata tudi, da so lastne prioritete akademikov glede internacionalizacije celo višje od tistih, ki jih navajajo njihove ustanove. Hkrati pa so preference akademikov glede različnih aktivnosti, ki so povezane $\mathrm{z}$ »internacionalizacijo študija doma «, še posebej predavanja v tujem jeziku, nižja in zelo raznolika, to pa bi lahko oviralo načrte vlade $\mathrm{v}$ tej točki.

Ključne besede: visokošolski poklic, visokošolska kultura, reforme visokega šolstva, Slovenija, internacionalizacija, mednarodno sodelovanje, internacionalizacija študija doma 


\section{Introduction}

Academics can drive higher education reforms or they can obstruct the implementation of the reforms intended by governments and institutional leaders. As suggested by Clark (1983), significant authority, both formal and informal, rests with individual faculty members when it comes to the implementation of university policies. Institutional changes are to a large extent dependent on how the leadership manages to obtain support from academics, who are the final arbiters of how university life takes place (ibid.). The behaviours, attitudes and values of academics are part of the "black box" of contextual conditions that often remain underexplored in research but are recognised as having a decisive influence on the implementation of higher education reforms at the institutional level (Elken et al., 2010). Like other institutions, higher education institutions are relatively enduring collections of "rules and organised practices, embedded in structures of meanings and resources" (March \& Olsen, 2008, p. 3). What makes the rules and practices in higher education institutions particularly enduring is the rather slow turnover of the institutional backbone: the academics. The tenure of academics typically spans several decades. Within an institution, academics form tightly knit social networks through which the perceptions of what constitutes academic roles and university operations are diffused and perpetrated. In order to understand the implementation of higher education reforms, it is therefore crucial to understand both the culture and climate of the academic community.

Academic culture refers to the deeply shared values and beliefs of members of academic institutions, while academic climate consists of common member perception of attitudes towards academic work and university life (Peterson \& Spencer, 2006). Together, they contain the patterns of behaviour and the shared values that academics hold regarding university life, their understanding of academic duties, their conceptions of what constitutes academic success, and the meaning they give to their academic roles and purposes as well as those of their respective institutions. Consequently, academic culture and climate are important facets of the contextual conditions that either enable the implementation of particular reforms or present a deterrent, or even an insurmountable obstacle, to such implementation. As several scholars have suggested (Musselin, 2013; Altbach, 2002; Enders, 2001; Slaughter \& Leslie, 1997), government policies do not necessarily influence academic values, but they do influence the academic climate - the academics' understanding of what constitutes expected and desired behaviour - thus influencing the activities in which academics engage. 
The implementation of an internationalisation agenda in higher education institutions is no exception to this dynamic. Academics are a vital agency of internationalisation in research and teaching, as well as in forming strategic partnerships that include other areas, such as development projects. The present article is concerned with the question of how conducive the academic climate in Slovenian higher education institutions is to internationalisation. Our underlying assumption is that academic staff represent either an important driving force or an obstacle to the implementation of policies formulated at the national level and diffused into the institutional practices. If proposed higher education reforms run against the preferences of academic staff, it may be rather difficult, if not impossible, to successfully implement such reforms, or they may be implemented on paper but not in practice. Specifically, we investigate whether the present academic attitudes and behaviours are in line with the internationalisation aims and objectives as stated in the National Higher Education Programme. In Slovenia, the National Higher Education Programme serves as the key government public policy document in the area of higher education. It has a direct influence on the regulatory framework, and consequently on the policies and strategies of higher education institutions. In the latest $\mathrm{Na}$ tional Higher Education Programme (NHEP, 2011) for the period 2011-2020, adopted by the Slovenian Parliament in 2011, internationalisation is highlighted as one of the pillars of the reform agenda.

The present article stems from the first comprehensive study of conditions of academic work conducted in Slovenia, which was conducted in 2013 based on the EUROAC questionnaire. The questionnaire included questions on overall work conditions, teaching, research, management and career, as originally conceived in the EUROAC project (Teichler \& Hoehle, 2013; Kehm \& Teichler, 2013, Teichler et al., 2013). We have added a section on international cooperation and internationalisation.

An online survey was sent to 5,791 academic staff employed at Slovenian higher education institutions, and was fully completed by a total of 728 respondents, representing a $13 \%$ response rate. The structure of the respondents by their grades is: professors (14.4\%), associate professors (16.3\%), assistant professors $(26.4 \%)$, and assistants/junior researchers $(26.8 \%)$. Other academic grades in total represented only $16.1 \%$ of respondents. The majority of the respondents obtained their doctoral or postdoctoral degree in 2000 or later (67.3\% for doctoral degrees and $69.2 \%$ for postdoctoral degrees), and $80.2 \%$ of the respondents were elected to their current title in the last 5 years. However, the year of the respondents' first full-time appointment in higher education is rather equally distributed, ranging from up to 5 years ago $(18.1 \%)$ to up to 30 
years ago (15.7\%), with most respondents (24.4\%) being appointed 6-10 years ago. There was also fairly equal representation regarding the disciplines and individual institutions: from natural sciences and engineering (41.9\%), and from social sciences and humanities (38.8\%). Responses from individual institutions were represented with a balanced share in the range $11-14 \%$, with most respondents coming from the University of Ljubljana, which is also Slovenia's largest and oldest university.

Due to the nature of the questionnaire, which is highly complex and long, the response rate is rather low, but it is similar to response rates to the same survey when it was conducted in other European countries (Teichler \& Hoehle, 2013; Kehm \& Teichler, 2013, Teichler et al., 2013). We have triangulated the data obtained through the survey with data obtained from 21 semi-structured in-depth interviews with academics at the three public universities (each interview lasted on average 60 minutes). The interview data largely confirmed the survey responses, which points to the reliability of data despite the low response rate. The same conclusion was reached by Horta (2013) (citing Krosnik, 1999), who suggests that "while a low response rate could be problematic, studies demonstrate that datasets resulting from low response rates can yield more accurate measurements and quality than those with greater response rate levels" (Horta, 2013, p. 493). Furthermore, the survey sample was sufficiently representative with regard to all of the main categories of academic staff profiles, e.g., disciplines of departments in which the respondents are employed, gender and academic rank (for details, see Klemenčič \& Flander, 2013), and meeting the criteria of representativeness is more relevant than the response rate for the generalisability of the survey research (Horta, 2013). Finally, the EUROAC survey represents the very first in-depth analysis of the academic profession in Slovenia, and therefore does not yet allow for historical comparison of changes. There exist no other comparable studies of academic culture and climate in Slovenia to which the present article could refer.

In summary, the key question to be explored in the present article is the extent to which the attitudes and behaviours of academics are compatible with the governments' objectives and projected measures for higher education reforms in the area of internationalisation: Are the objectives stated in the NHEP already part of the Slovenian academic climate, or do they go against existing academic preferences and behaviours? 


\section{The internationalisation of higher education in Slovenia and the National Higher Education Programme}

Slovenia has experienced profound reforms of higher education in the last two decades. The reforms have been driven by broad socioeconomic developments, such as the reform of public institutions in the context of statehood-building and democratisation, accession to the European Union and to internationalisation more broadly, and the enhanced relevance of knowledge and the associated changing role of higher education institutions within developing knowledge societies (Zgaga, 2010, 2012). Internationalisation emerges as an objective in all past national higher education programmes. The National Higher Education Programme 2006-2010 states the objective that at least 5\% of lecturers employed in all higher education institutions should be foreign lecturers, that the programmes offered should be attractive to foreign students, and that the number of foreign postdocs should increase (NHEP, 2006, p. 38). The Programme also highlights the importance of offering programmes in English alongside study programmes in Slovenian, and of engaging in joint and double degree programmes (ibid.). Furthermore, the Higher Education Master Plan of 1998 (Zgaga, 1998, pp. 55-56) clearly states that: "As a result of modern globalisation processes, participation in international cooperation and the international division of work cannot be avoided in higher education. In smaller higher education systems, it encourages the quality of and an innovative approach to their activity, which is ensured in large ones by the variety of national institutions... Special effort should be made to ensure ...student and faculty exchanges, joint design and provision of study programmes and participation in quality assessment systems...”.

In the scholarly literature, internationalisation is defined as "the process of integrating an international, intercultural or global dimension into the purpose, functions or delivery of higher education" (Knight, 2004, p. 9). A related definition useful for our purposes is that internationalisation is "the variety of policies and programs that universities and governments implement to respond to globalisation" (Altbach, Reisberg, \& Rumbley, 2009, p. 7). While globalisation is seen to be beyond the control of any one actor or set of actors, internationalisation is indeed a strategy that is formulated and implemented by higher education institutions, governments and other actors active in the field of higher education to handle globalisation (Altbach, Reisberg, \& Rumbley, 2009, p. 23-35). An internationalisation strategy thus permeates the purpose, functions, and delivery of higher education (Knight, 2003, p. 2). Such a strategy may consist of different elements, of which student and staff mobility, 
research collaboration and the "internationalisation of study at home" are most frequently emphasised (Qiang, 2003, pp. 258-259). The internationalisation of study at home entails internationalising the curriculum, and teaching and learning in an international classroom. It has surfaced as an important objective due to the realisation that, although the majority of students remain nonmobile, they too should develop international knowledge and competences (Crowther et al., 2000; Waecher, 2003).

There are two widely recognised arguments as to why the internationalisation of higher education is important (Qiang, 2003). First, higher education needs to prepare graduates adequately for life and work in increasingly globalised environments by adding intercultural skills, attitudes and multilingualism to their learning outcomes (ibid.). Second, research requires collaborative efforts and intensive international collaboration due to increasing specialisation and the size of investments needed in certain areas of research (ibid.). This is particularly true for small systems, such as the Slovenian higher education and research system. Despite the overall agreement in academic and policy circles on the benefits of internationalising higher education, the actual policies and practices vary significantly across higher education systems and institutions (Klemenčič \& Flander, 2013). The reasons for these differences lie as much in administrative and financial obstacles to internationalisation as in differences in motivation, and even in national and institutional conceptions of the role internationalisation should play in Slovenian higher education institutions.

These arguments pervade the National Higher Education Programme 2011-2020, which was conceived within the context of the Slovenian Development Strategy and the European Union's growth strategy "Europe 2020" (European Commission, 2010), both of which place a strong emphasis on education as one of the key pillars of economic growth and social development. The NHEP (2011, p. 41) explicitly states that the "[i]nternationalisation of Slovenian higher education is a key to its development since it is a feature of its quality". The intention of the government was for the internationalisation strategy to be one of the seven main pillars identified as crucial for the development of Slovenian higher education. The key internationalisation measures to be achieved by 2020 include: teaching and research will take place in cooperation with foreign institutions, teachers and researchers; study programmes will be carried out for mixed groups of students from different countries; and the number of joint study programmes with foreign institutions will increase significantly. Specific measures also include strengthening regional cooperation and the mobility of academics and students with the closest neighbouring regions (especially the Western Balkans and Euro-Mediterranean regions). 
Following the changes in government and the financial crisis, the implementation of the NHEP has slowed down and many steps and actions have not yet been realised. Most importantly, the national internationalisation strategy has not yet been drafted, thus leaving the implementation of the NHEP objectives to the interpretations of institutions.

However, given the small size of the country, international academic cooperation has long been promoted, being increasingly linked to notions of research excellence. Publishing with international publishing houses and in recognised international journals, as well as invitations to speak at international scientific conferences or to teach at foreign universities, are regarded in academic circles as a sign of academic achievement (Klemenčič \& Zgaga, forthcoming). As early as in the 1990s, the University of Ljubljana formed a rule that promotion to a professorial title is not possible if the candidate has not worked for at least three months at a foreign university; similar rules were soon adopted by other institutions and have recently been extended to associate professors. In 2010, both conditions were included in national guidelines on the minimal criteria for academic appointments issued by the Slovenian National Quality Assurance and Accreditation Agency (Klemenčič \& Zgaga, forthcoming). Finally, since the early 1990s, the range of opportunities for international academic cooperation has expanded with the participation of Slovenia in European Union programmes, especially TEMPUS and later SOCRATES, as well as framework programmes financing research cooperation (Zgaga, 1998). These programmes have certainly contributed to the opportunities for Slovenian academics in international cooperation, and have arguably also affected the attitudes of academics towards internationalisation. These attitudes, as well as the international activities of Slovenian academics, are explored in the next section.

\section{Findings from the EUROAC 2013 survey}

\section{Personal and institutional priorities regarding internationalisation}

The findings from our survey show that Slovenian academics indeed value internationalisation and seek international cooperation. However, there are some discrepancies between the preferences and behaviours of academics and the objectives stated in the NPHE. First, publishing with international journals and publishers, using international literature, participation in international collaborative projects and topics in teaching, and following developments in academic literature internationally within one's own discipline are ranked the 
highest by all academic ranks; for example, $86.4 \%$ of academics attach high importance or importance to publishing in international journals, while $96.1 \%$ emphasise using international literature. A much lower number of academics - although still in positive values - prioritise activities typically associated with the internationalisation of study at home: contributing to the formulation of joint/double degree programmes (45.8\%), offering courses in a foreign language (50.7\%), and encouraging foreign students (56.6\%) and foreign scholars (68\%) to visit the home institution. The same findings (for the lowest and highest ranked priorities) can be identified if we examine the responses according to academic fields.

However, the Slovenian academic community appears fairly divided on questions regarding conducting lectures in foreign languages (standard deviation 1.176). Similarly, there are rather divergent views in terms of personal priorities with regard to contributing to joint and double degree programmes (standard deviation 1.118) and encouraging foreign students to study at the home institution (standard deviation 1.100). This means that on questions concerning the implementation of the internationalisation of study at home, the priorities of Slovenian academics are clearly far from unified. The most convergent attitudes of Slovenian academics are related to personal priorities for following foreign literature in order to stay up-to-date with developments in the field, with regard to which the personal priorities of academics are also the highest.

Another interesting finding is that the academics' own priorities regarding internationalisation activities tend to be higher than the perceived priorities of their respective higher education institutions (Table 1), even though institutional expectations are in general perceived as fairly high. The lowest institutional expectations regarding internationalisation are related to foreign language lectures at the home institution (2.93). This corresponds to the established practice in Slovenia that foreign languages are only used in courses offered within international programmes, and on the condition that the course is simultaneously also offered in Slovenian (Klemenčič \& Flander, 2013; Golob Kalin et al., 2012). 
Table 1. Academics' personal priorities and institutional expectations regarding internationalisation (five-point scale ranging from $1=$ not important at all, to $5=$ very important for personal priorities, and from $1=$ low to $5=$ high for institutional expectations).

\begin{tabular}{l|c|c|c|c|c|c}
\hline & \multicolumn{3}{|l|}{$\begin{array}{l}\text { Personal priorities regarding } \\
\text { international cooperation }\end{array}$} & \multicolumn{2}{|l}{ Institutional expectations } \\
\cline { 2 - 7 } & Mean & $\mathrm{N}$ & St. dev. & Mean & $\mathrm{N}$ & St. dev. \\
\hline $\begin{array}{l}\text { Cooperation with foreign re- } \\
\text { searchers in research projects }\end{array}$ & 4.30 & 686 & 0.853 & 3.63 & 687 & 1.223 \\
\hline $\begin{array}{l}\text { Preparation of publications with } \\
\text { co-authors from abroad }\end{array}$ & 4.03 & 682 & 0.980 & 3.37 & 681 & 1.218 \\
\hline $\begin{array}{l}\text { Publishing in international } \\
\text { journals and with international } \\
\text { publishers }\end{array}$ & 4.46 & 685 & 0.840 & 4.35 & 682 & 1.010 \\
\hline $\begin{array}{l}\text { Following developments in aca- } \\
\text { demic literature internationally } \\
\text { within one's own discipline }\end{array}$ & 4.76 & 684 & 0.532 & 4.00 & 682 & 1.114 \\
\hline $\begin{array}{l}\text { Student mobility from home } \\
\text { institution to foreign institutions }\end{array}$ & 3.90 & 688 & 1.070 & 3.48 & 690 & 1.158 \\
\hline $\begin{array}{l}\text { Student mobility from foreign } \\
\text { institutions to home institution }\end{array}$ & 3.64 & 685 & 1.100 & 3.42 & 682 & 1.155 \\
\hline $\begin{array}{l}\text { Mobility of academics from home } \\
\text { institution to foreign institutions }\end{array}$ & 4.09 & 686 & 0.955 & 3.43 & 684 & 1.181 \\
\hline $\begin{array}{l}\text { Mobility of academics from } \\
\text { foreign institutions to home } \\
\text { institution }\end{array}$ & 3.94 & 684 & 0.990 & 3.24 & 682 & 1.218 \\
\hline $\begin{array}{l}\text { Foreign lecturers lecturing at } \\
\text { home institution }\end{array}$ & 4.10 & 684 & 0.925 & 3.41 & 677 & 1.161 \\
\hline $\begin{array}{l}\text { Foreign language lectures at } \\
\text { home institution }\end{array}$ & 3.47 & 685 & 1.176 & 2.93 & 683 & 1.221 \\
\hline $\begin{array}{l}\text { Using international literature and } \\
\text { topics in teaching }\end{array}$ & 4.45 & 685 & 0.779 & 3.65 & 679 & 1.196 \\
\hline $\begin{array}{l}\text { Formulation of joint/double } \\
\text { degree programmes }\end{array}$ & 3.38 & 674 & 1.118 & 3.05 & 670 & 1.194 \\
\hline
\end{tabular}

The findings also point to a high diversity of institutional priorities regarding internationalisation activities as perceived by academics (Figure 1). Other research has pointed out that Slovenian higher education institutions harbour very different ambitions regarding internationalisation, and that their internationalisation strategies are far from equally elaborate (Braček Lalić, 2007). Based on the perceptions of academics, our observation is that only a few institutions in Slovenia aspire to or have a strategy for competing on the global higher education market. We also observe that rationales and objectives 
for internationalisation differ between the university and faculty levels: the university strategy does not necessarily represent the lowest common denominator of faculty strategies. The standard deviation of answers on all points was above 1.161, with the exception of publishing in international journals, which was ranked the highest and displayed the most convergence. Finally, $46.4 \%$ of academics agreed or strongly agreed with the statement that their institution places high emphasis on internationalisation, with the views on this issue again being fairly divergent (standard deviation 1.177).

A comparison of personal and institutional priorities with regard to internationalisation points to the favourable attitudes in the academic climate to drive internationalisation, providing appropriate conditions and support measures are created. At the same time, the data also indicates reasons for caution. The preferences of academics tend to be highly divergent on questions concerning the internationalisation of study at home. It appears that these activities interfere more directly with the academics' usual work routines. The different priorities are fuelled by ideological differences regarding the protection of Slovenian language and culture. They also reflect different views as to the purposes and benefits of internationalisation.

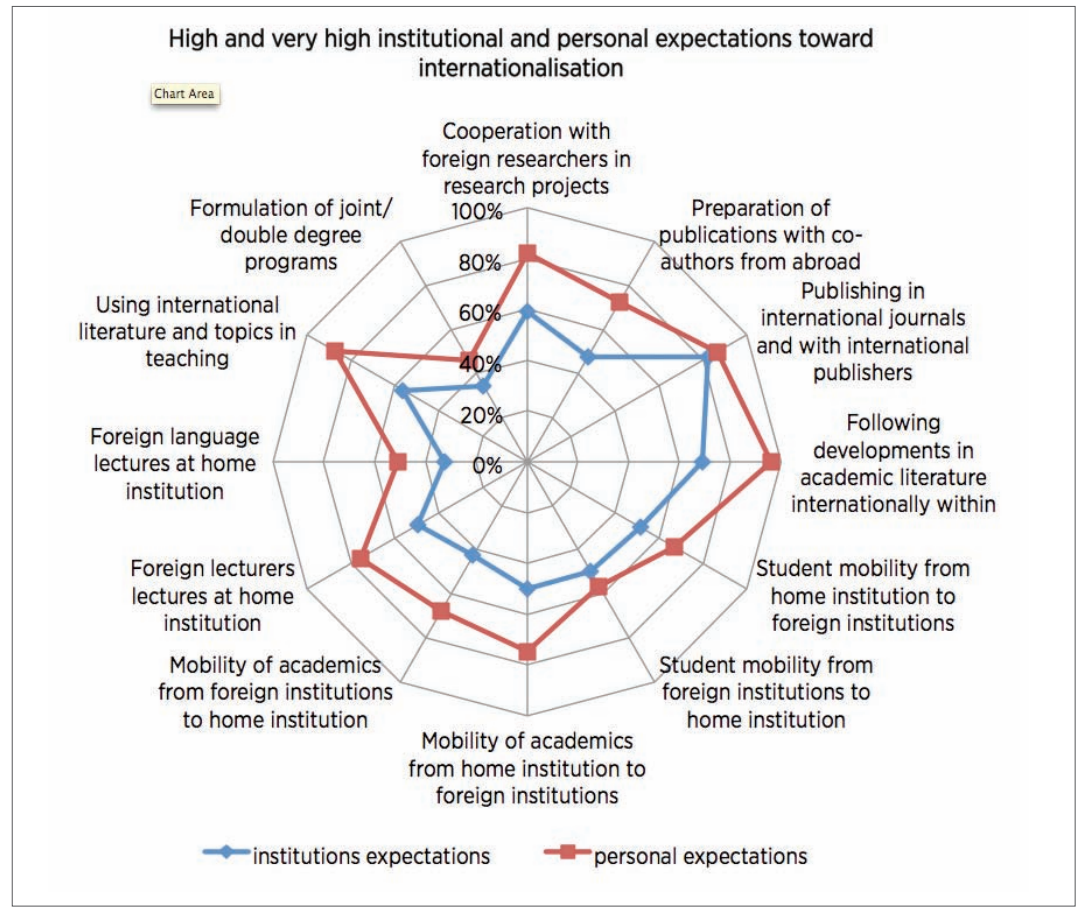

Figure 1. Institutional and personal expectations regarding internationalisation (percentage) (responses 4 and 5 on a scale $1=$ not important, to $5=$ very important). 
Data show that elements important for internationalisation at home are not high on the personal priority list of academics, as well as being rather low among the perceived institutional priorities regarding internationalisation. This could be explained by the legislation regarding the official language of instruction, and by the shortage of funds for offering courses in foreign languages in parallel to the same courses being offered in Slovenian. These factors place the issue of the more systematic implementation of international curricula very low on the institutions' agenda.

\section{International cooperation with the Western Balkans}

One of the explicit aims of the National Higher Education Programme (2011) is to strengthen academic cooperation with the Balkan region (former Yugoslav countries). This objective is justified by the ambition to attract students and staff, especially in view of declining demographics, and by the desire to strengthen Slovenian research. The objectives also serve the broader political goals of strengthening cultural, economic and political cooperation within the region, in order to act as a strategic alliance of small states within the context of the European Union. Regional cooperation is an excellent springboard for common initiatives and common projects within the European Higher Education Area (EHEA).

These objectives, however, stand in marked contrast to the present realities in terms of Slovenian academics' attitudes to cooperation with the countries of the Western Balkans (Table 2). In an opinion survey conducted in eight Western Balkan countries, including Slovenia, Zgaga et al. (2013) report that only $20.3 \%$ of Slovenian academics agreed that their institution should primarily seek cooperation with institutions in this region, which was the lowest result in the region. Slovenian academics stated significantly higher preferences for regional cooperation with Eastern European countries than with Western Balkan countries (ibid.). Our findings from EUROAC largely confirm these findings. We have established a relatively low level of existing academic cooperation with the Western Balkans, as self-reported by our respondents. Only about one quarter of academics teaching abroad in the last three years report teaching in countries of former Yugoslavia or collaborating in research with colleagues from these countries, and only $17.2 \%$ of reported joint publications were undertaken in collaboration with academics from the region. The highest reported cooperation was by associate professors through international research projects. Only $4.2 \%$ of the academics teaching in the Western Balkans reported that this represented more than half of their overall teaching abroad. 
Regarding research, the percentage is even lower (3.2\%), in terms of both joint publications and research collaboration.

Senior academics are in general more internationally engaged in terms of obtaining funding and research/publishing cooperation; again in this case, however, the level of cooperation with academics from former Yugoslavia is rather low. Amongst full professors who cooperated with colleagues from abroad, cooperation with researchers from ex-Yugoslav countries represents $31.3 \%$ of their international cooperation activities, while for associate professors the figure is $40.2 \%$, for assistant professors $27.8 \%$, and for assistants only $11.6 \%$. Percentages of joint publications with Balkan colleagues (those with joint international publications within the last three years) are even lower: the highest is for associate professors (32.6\%) and the lowest for assistants (8.1\%).

In our study, academics reported that employment of foreign academics from former Yugoslavia countries has decreased; however, it should be noted that employment of foreign academics from other countries is also reported to be decreasing or stagnating. On the other hand, there were 3,185 students with foreign citizenship enrolled in the 2012/13 academic year, representing $3.3 \%$ of the entire student population. Over $75 \%$ of these students were from ex-Yugoslav countries, which is a considerable share.

Table 2. Self-reported international activities of academics according to rank (five-point scale ranging from $1=$ strongly decreased, to $5=$ strongly increased).

\begin{tabular}{lccc}
\hline $\begin{array}{l}\text { What has the level of development of the following activities } \\
\text { been at your institution in the last three years? }\end{array}$ & Mean & N & St. dev. \\
\hline $\begin{array}{l}\text { Employment of foreign academics from former Yugoslavia } \\
\text { countries }\end{array}$ & 2.27 & 673 & .971 \\
\hline Employment of foreign academics from other countries & 2.38 & 676 & 1.097 \\
\hline Participation in student exchange mobility & 3.42 & 687 & .956 \\
\hline International cooperation at the institutional level & 3.32 & 685 & .936 \\
\hline
\end{tabular}

In summary, the existing academic cooperation with colleagues from the Western Balkans is reported to be rather low, but shows sufficient potential to build on in the future. Inspiration on how to strengthen such cooperation may well be taken from the Austrian initiative launched under their presidency in 2006, in the form of the Steering Platform on Research for the Western Balkans. Several research projects, aimed at exchanging information and national policy developments, have been supported by European programmes or directly by the Austrian Federal Ministry, focusing on the Southern European or Western Balkans Research Area (Klemenčič \& Zgaga, 2013). 


\section{Academics' existing involvement in international cooperation in teaching and research}

Academics in Slovenia tend to be intrinsically motivated to cooperate with colleagues abroad. Our respondents appear fairly internationally oriented, both in research and teaching. They also tend to publish abroad, especially academics with higher academic titles. However, as always, the self-reported data on publications and teaching abroad should be considered with caution, due to the possibility of social desirability bias. In our survey, $35.2 \%$ of academics reported teaching in joint programmes, and over $60 \%$ reported working with incoming foreign students, which is surprisingly high and contradicts some of the findings from the survey of Erasmus students conducted parallel to the present survey (Klemenčič \& Flander, 2013), as well as being absent from the interviews conducted parallel to the survey. Regarding teaching abroad, about half of the Slovenian academics surveyed (45.10\%) reported having this experience in the last three years. More than half of senior academics have taught in a foreign language at a home institution and lectured abroad within the last three years. The share of those who have either lectured abroad or in a foreign language decreases with academic rank (Klemenčič \& Flander, 2013).

The share of those involved in international cooperation in research is much higher than in teaching. In our EUROAC survey, $43.5 \%$ of academics reported having participated in international research project groups, with $14.4 \%$ also managing such projects. Some $79.5 \%$ respondents reported collaboration with international colleagues. Almost $70 \%$ also reported their articles being published in an international academic book or journal. International research collaboration is indeed significantly better funded than teaching opportunities abroad. In addition, deliverables from international research collaboration, such as publications in international journals and with international publishing houses, score highly in criteria for academic appointments (Klemenčič \& Flander, 2013). However, we are aware that here we rely on individuals' subjective estimations rather than actual publishing records, which exist for all Slovenian academics in the Co-Operative Online Bibliographic System and Services of Slovenia (COBISS), so these data should also be treated with caution, as they are highly susceptible to social desirability bias. Nonetheless, other sources confirm that Slovenian researchers are amongst the most productive in Europe in terms of papers published, with Slovenia occupying sixth place within the EU27 (Kolar, 2011). This shows the strong inclination of Slovenian academics towards research productivity. The reason lies mostly in the fact that, for a long time, the number of articles published was one of the most important criteria for funding 
project evaluations undertaken by the Slovenian Research Agency (ARRS), and is, of course, also an important criterion in academic promotions (ibid.). Furthermore, based on scientific publications in co-authorship with foreign researchers (per million inhabitants), Slovenia is in ninth place within the EU27, with 749.7 publications, and is thus ranked higher than countries such as Germany, France, the Czech Republic and Estonia (European Commission, 2011).

In terms of the academic job market, Slovenia is almost entirely closed to international academics (Klemenčič \& Zgaga, forthcoming). The reasons for this are several, but revolve around the fact that Slovenia is not a notable study destination for foreign students, that it practices limited internationalisation of study at home, and that there are certain legal requirements for instruction at higher education institutions in Slovenia to be undertaken in Slovenian (Klemenčič \& Flander, 2013). The responses in the EUROAC survey show that 96.3\% of the participating academics graduated in Slovenia, 90.6\% hold a Slovenian masters degree and $76.5 \%$ a Slovenian doctoral degree. Over half of the academics surveyed have never been employed by any institution other than their current employer, and have obtained all of their degrees within the same institutions. This indicates an inbreeding problem within the Slovenian higher education system that is, however, slowly being overcome, mostly thanks to the emergence of new institutions, but reinforced by the culture of measuring research excellence (Klemenčič \& Zgaga, forthcoming). The NHEP, as well as the Resolution on Research and Innovation Strategy of Slovenia 2011-2020 (RISS), are therefore also aimed at strengthening the qualifications of academic and research personnel, and ensuring effective inter-institutional and interstate mobility for researchers. However, given the existing policy on Slovenian language as the language of instruction, employing foreign researchers might precede employing academics for teaching (ibid.).

\section{Existing institutional support for internationalisation}

Compared to the importance attributed to internationalisation, the actual level of satisfaction of academics with various forms of institutional support is fairly low. Academics are least satisfied with opportunities at their home institution for finding funds for international cooperation activities, and they are most satisfied (although still with a rather low level of satisfaction) with institutional support to foreign students (Klemenčič \& Flander, 2013).

Whereas internationalisation certainly figures as a policy priority for the government, institutions and individual academics, the actual support for international cooperation on the part of institutions does not appear to be 
adequate. Academics are most satisfied with the institutional support to visiting international students (39.3\%), and least satisfied with opportunities within the home institution to find funds to support international cooperation activities (61.7\% highly dissatisfied or dissatisfied). Only $37.8 \%$ of academics are satisfied with support given to visiting scholars, while $76.4 \%$ believe that this support is very important. One of the lowest results on the satisfaction scale is the definition of internationalisation objectives at the home institution, with only $20.9 \%$ of respondents reporting being satisfied with their home institution's internationalisation objectives.

Analysis of the importance and satisfaction of conditions by rank shows that the same opinion is shared regardless of academic rank (Figure 2). All elements are considered important or very important by a high percentage of academics within all ranks (80\% on average). Very convergent responses can also be seen for satisfaction with the actual conditions within the respondents' universities; however, only a small percentage of academics of all ranks are satisfied or very satisfied with these conditions ( $25 \%$ on average).

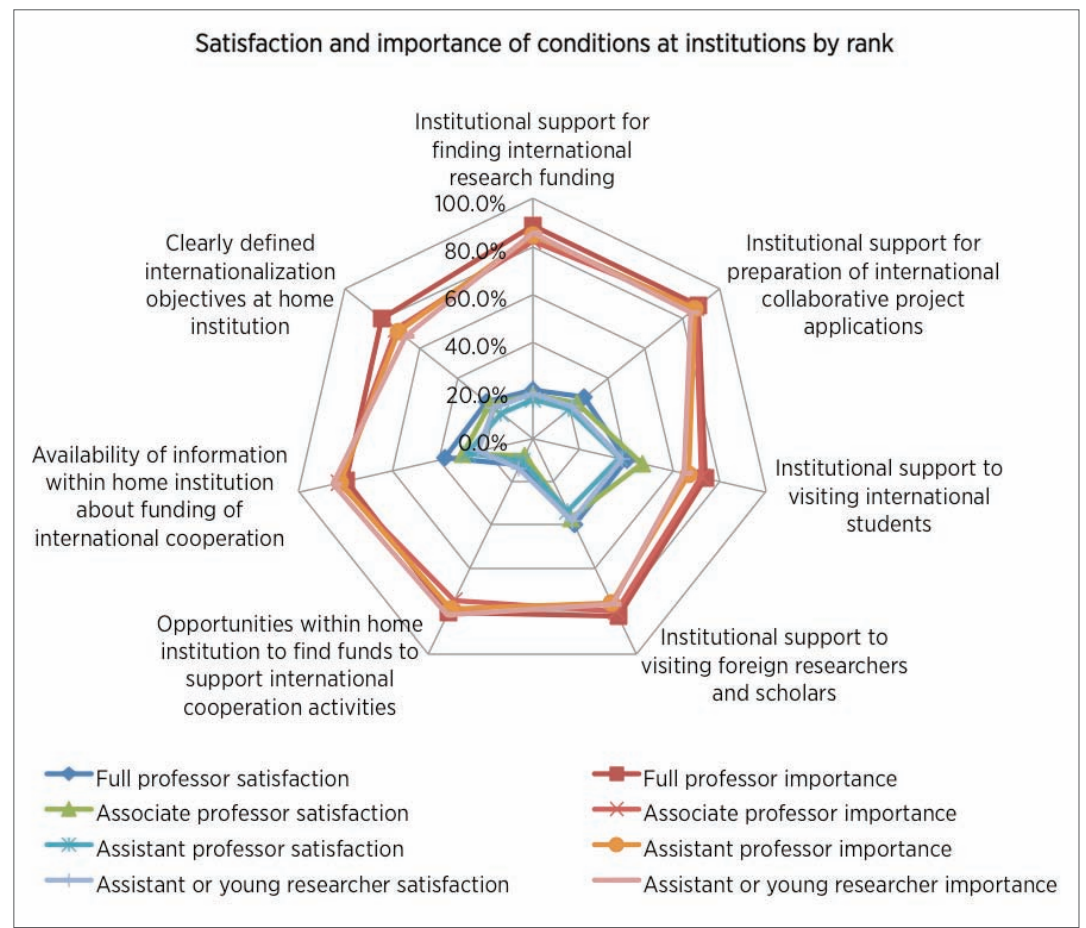

Figure 2. Satisfaction and importance of conditions at institutions by rank (percentage) (responses 4 and 5 on a scale $1=$ not important to $5=$ very important, and $1=$ not satisfied to $5=$ very satisfied). 
The most divergent responses can be seen in terms of satisfaction with the availability of information within the home institution regarding the funding of international cooperation, where this information seems to be more accessible to higher ranks. In terms of importance given to particular conditions for internationalisation, the highest level of divergence is in relation to the clarity of defined internationalisation objectives at institutions, with its importance dropping according to rank (80.2\% for full professors, $69.7 \%$ for assistants).

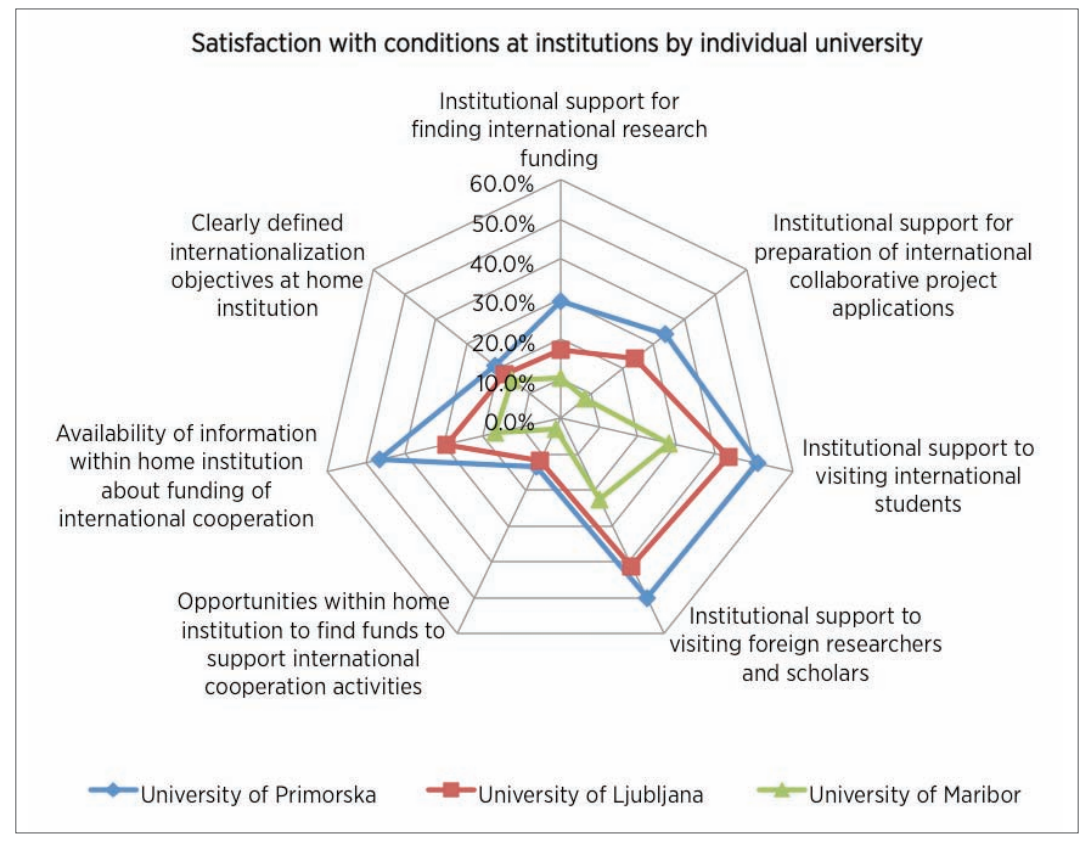

Figure 3. Satisfaction with conditions at the institutions by individual university (percentage) (responses 4 and 5 on a scale $1=$ not important to $5=$ very important and $1=$ not satisfied to $5=$ very satisfied $)$.

Responses related to the satisfaction of existing institutional support for internationalisation by individual university show a large degree of divergence (Figure 3). Even though approximately one quarter of all of the Slovenian academics participating in our survey are, on average, satisfied with conditions at their institutions, the level of satisfaction is much higher in some universities (for example, the University of Primorska, with average satisfaction of 35\%) than others (for example, the University of Maribor, with average satisfaction of $15 \%)$. In the University of Primorska, half of the respondents are satisfied with their institutional support for foreign students (50.9\%) and academics (50.0\%). 
Although these conditions are also rated as the most satisfactory in the other two universities, the percentage of satisfied and very satisfied academics at these institutions is much lower (Ljubljana on average $42.2 \%$, Maribor on average $25.4 \%$ ). Support for incoming students or academics is rated as the most satisfactory of all of the conditions evaluated within this question at all three universities.

Academics at the University of Primorska are also satisfied with the availability of information within the home institution concerning funding of international cooperation (46.6\%), while in the University of Maribor satisfaction in this regard is reported by only $16.8 \%$ of respondents. We could find no correlation between satisfaction and ranks within individual institutions.

\section{Conclusion}

In order to understand the possibilities for implementing the internationalisation agenda as part of higher education reforms in Slovenia it is important to understand the culture and climate of the academic community, the values, attitudes and present behaviours of academics. These particular contextual conditions can enable or obstruct the implementation of the reform agenda. The findings of the present study are also important for the formulation of the national strategy for the internationalisation of higher education in Slovenia, which is an "operational document" foreseen in the National Higher Education Programme (2011, p. 54, Objective 28).

Our findings show that Slovenian academics value internationalisation and seek international cooperation in general. However, there are some discrepancies between the values and behaviours of academics and the goals stated in the NPHE. These pertain in particular to various activities associated with internationalisation at home and to academic cooperation with the Western Balkans.

First, academics' own priorities regarding internationalisation activities tend to be higher than the perceived priorities of their respective higher education institutions, even though institutional expectations are in general perceived as fairly high. In particular, academics are highly supportive of mobility programmes and of involving foreign lecturers in either teaching or research collaboration. There is a clear window of opportunity here for institutions and the government to set a more ambitious internationalisation agenda.

Second, an ambitious internationalisation agenda, expectedly, also requires a fair amount of institutional support for internationalisation. The comparison of personal and institutional priorities regarding internationalisation points to the interest of academics in driving further internationalisation, 
providing appropriate conditions and support measures are created. Compared to the importance attributed to internationalisation, the actual satisfaction of academics with various forms of institutional support is fairly low. Particularly low is institutional support for finding funds to facilitate international cooperation activities, either within the institution or for international research collaboration. One of the lowest levels of satisfaction relates to the definition of internationalisation objectives at the home institution, while opportunities within home institutions to find funds also shows high dissatisfaction of academics.

Third, academics tend to be least positively inclined to various internationalisation activities linked to the "internationalisation of study at home". Given the low existing participation in mobility programmes $(1.51 \%$ for students and 3.45\% for staff) (Klemenčič \& Flander, 2013), activities such as courses in foreign languages, better integration of foreign students in the study process, invitations to foreign lecturers, etc. are essential for helping non-mobile students to develop international competences. While aggregate academic attitudes tend to be positive across the Slovenian higher education space on each of these questions, when it comes to the question of conducting lectures in foreign languages, attitudes tend to be highly divergent across institutions. In other words, the attitudes of academics concerning these questions are fairly divided, and are most divided on the question of lecturing in foreign languages. It appears that more has to be done in the Slovenian academic community to discuss this matter and arrive at some sort of consensual position.

Internationalisation at home means not only the sum of all of the international activities in an institution, but also a coherent relationship between these activities, brought about by some form of institution-wide coordination and central steering (Crowther et al., 20oo). This has shifted the priorities towards the encouragement of, for example, the internationalisation of curricula and programmes taught in foreign languages. Crowther et al. (2000) suggest that there could also be some "isolationist" undercurrents in parts of Europe, mainly due to sub-national regions and their governments who, in an attempt to foster regional identity, limit their institutions' marges de maneouvre, with mechanisms such as restrictive language policies. Slovenia is a case in point: most Slovenian institutions have no courses offered in a foreign language, but a foreign language can be used as a working language in parts of the teaching process, especially in lab work, seminars, tutorials and individual consultations if foreign students are enrolled (Klemenčič \& Flander, 2013). However, such an approach is not feasible for a large number of students in times of massive enrolments, and the desired massive student mobility in the future (Golob Kalin et al., 2012; Klemenčič \& Flander, 2013). Achieving an increased number of 
foreign students, which is set as a mid-term goal in many universities, would therefore require some radical changes.

Fourth, we also observe that cooperation with academics and institutions from ex-Yugoslav countries is not seen as a potential path to capitalising on established personal contacts, knowledge of languages and similarities in academic and research culture, and thus to enhancing international cooperation. Instead, such cooperation is marginalised due to other possibilities and opportunities for cooperation within Europe and its programmes and incentives, as well as the EHEA.

Finally, although the self-reported responses on the existing engagement in internationalisation activities indicate a fairly high level, this should be treated with caution, as it is highly susceptible to social desirability bias. In order to obtain reliable data, it would be necessary to consult the COBISS database, which was not done within the framework of the present study. Nevertheless, Slovenia is ranked fairly high in the European Union on the measure of scientific publications in co-authorship with foreign researchers per million inhabitants, which testifies to the wide acceptance of international research collaboration in Slovenian academic culture.

\section{References}

Altbach, P. G. (2002). The Decline of the Guru: The Academic Profession in Developing and MiddleIncome Countries. Chestnut Hill, MA: Center for International Higher Education, Boston College. Altbach, P. G., Reisberg, L., \& Rumbley, L. E. (2009). Trends in Global Higher Education: Tracking an Academic Revolution. Rotterdam: Sense Publishers.

Braček Lalić, A. (2007). Internacionalizacija visokega šolstva v Sloveniji. Master's Thesis. University of Ljubljana, Faculty for Social Sciences.

Clark, B. R. (1983). The higher education system: academic organization in cross-national perspective. Berkeley: University of California Press.

Crowther, P., Joris, M., Otten, M., Tekkens, H., \& Wächter, B. (200o). Internationalisation at home: A position paper. Amsterdam: EAIE.

Elken, M., Gornitzka, Å., Maassen, P., \& Vukasovic, M. (2011). European Integration and the Transformation of Higher Education. Oslo: University of Oslo, Department of Educational Research. Enders, J. (Ed.) (2001). Academic Staff in Europe: Changing Contexts and Conditions. Westport, CT, London: Greenwood Press.

European Commission. (2010). Communication from European Commission: Europe 2020. A strategy for a Smart, Sustainable and Inclusive growth. Brussels: European Commission. European Commission. (2011). European Innovation Union Scoreboard. The Innovation Union's performance scoreboard for Research and Innovation. Brussels: European Commission. 
Golob Kalin, M., Stabej, M., Stritar, M., \& Červ, G. (2012). Primerjalna študija o učnem jeziku $v$ visokem šolstvu $v$ Republiki Sloveniji in izbranih evropskih državah. Ljubljana: Ministrstvo za izobraževanje, znanost, kulturo in šport.

Horta, H. (2013). Deepening our understanding of academic inbreeding effects on research information exchange and scientific output: new insights for academic based research. Higher Education, 487-510.

Kehm, B., \& Teichler, U. (Eds.) (2013). The Academic Profession in Europe: New Tasks and New Challenges. In The Changing Academy - The Changing Academic Profession in International Comparative Perspective, Vol. 5. Dordrecht: Springer.

Klemenčič, M., \& Flander, A. (2013). Evaluation of the impact of the ERASMUS Programme on higher education in Slovenia. Ljubljana: Center RS za mobilnost in evropske programme izobraževanja in usposabljanja (CMEPIUS).

Klemenčič, M., \& Zgaga, P. (2013). Internationalisation at the European periphery and academics' geographic preferences for partnership: focus on the Western Balkans. In Weaving the future of global partnerships: A conversation starter for the EAIE 2013 Annual Conference. Amsterdam: European Association for International Education.

Klemenčič, M., \& Zgaga, P. (forthcoming). Academic Inbreeding in Slovenia. In P. Altbach, L. Rumbley, \& M. Yudkevich (Eds.), Academic Inbreeding: Causes and Consequences.

Knight, J. (2004). Internationalization Remodelled: Definitions, Approaches, and Rationales. Journal of Studies in International Education, 8(1), 5-31.

Kolar, J. (2011). Posnetek stanja raziskovalnega in inovacijskega sistema v Republiki Sloveniji. In Drzna Slovenija. Dodatek. Ljubljana: Ministry of Higher education, Science and Technology. March, J. G., \& Olsen, J. P. (2008). Elaborating the "New Institutionalism”. In R. A. W. Rhoades, S.

A. Binder, \& B. A. Rockman (Eds.), The Oxford Handbook of political institutions (pp. 3-20). Oxford:

Oxford University Press.

Musselin, C. (2013) Redefinition of the relationships between academics and their university. Higher

Education, 65(1), 25-37.

National Higher Education Programme. (2006). Resolution on National Higher Education Plan of Republic of Slovenia 2006 - 2010. Ljubljana: Ministry of Higher Education, Science and Technology. National Higher Education Programme. (2011). Resolution on National Higher Education Plan of Republic of Slovenia 2011 - 2020. Ljubljana: Ministry of Higher Education, Science and Technology.

Retrieved January 102014 from http://www.uradni-list.si/1/content?id=103885

Peterson, M. W., \& Spencer, M. G. (1990). Understanding Academic Culture and Climate. New Directions for Institutional Research, 68,17(4), 3-18.

Qiang, Z. (2003). Internationalization of Higher Education: towards a conceptual framework. Policy Futures in Education, 1(2), 248-270.

Slaughter, S., \& Leslie, L. L. (1997). Academic Capitalism: Politics, Policies, and the Entrepreneurial University. Baltimore: John Hopkins University Press.

Teichler, U., \& Höhle, E. A. (Eds.) (2013). The Work Situation of the Academic Profession in Europe: 
Findings of a Survey in Twelve Countries. In The Changing Academy - The Changing Academic Profession in International Comparative Perspective, Volume 18. Dordrecht: Springer.

Teichler, U., Arimoto, A., \& Cummings, K. W. (Eds.) (2013). The Changing Academic Profession. Major Findings of a Comparative Survey. In The Changing Academy - The Changing Academic Profession in International Comparative Perspective, Vol. 1. Dordrecht: Springer.

Wächter, B. (2003). An introduction: Internationalization at home in context. Journal of Studies in International Education, 7(1), 5-11.

Zgaga, P. (1998). Development of higher education in Slovenia. Ljubljana: Ministry of Education and Sport of the Republic of Slovenia.

Zgaga, P. (2010). The role of higher education in national development: South-Eastern Europe and reconstruction of the Western Balkans. In The Europa world of learning 2011, 61st ed. (pp. 19-24).

London; New York: Routledge.

Zgaga, P. (2012). Editorial. Centre for Educational Policy Studies Journal, 2(4), 5-8.

Zgaga, P., Klemenčič, M., Komljenovič, J., Miklavič, K., Repac, I., \& Jakačić, V. (2013). Higher

education in the Western Balkans: Reforms, developments, trends. Key findings from field research.

Ljubljana: Centre for Educational Policy Studies. Faculty of Education, University of Ljubljana.

\section{Biographical note}

Alenka Flander is the Director of the Centre of the Republic of Slovenia for Mobility and European Educational and Training Programmes (CMEPIUS), key institution for supporting international cooperation in education in Slovenia. Her research work is interdisciplinary in nature and encompasses monitoring and measuring the impact of European Programmes in the area of education and training, and research on internationalisation and higher education. She is a member of several EU expert groups on the EU's education programmes and expert groups in Slovenia (e.g. EUROSTUDENT). She specialises in both quantitative and qualitative methods of data collection and analysis.

Manja KLemenčıč is Lecturer in Sociology at the Department of Sociology at Harvard University. Her research is broadly in the area of comparative politics, political sociology and higher education. She is Editor-in-Chief of European Journal of Higher Education, a member of Editorial Board of Journal of Higher Education and Finance, Higher Education in Russia and beyond (HERB) and a member of International Editorial Advisory Board of Journal of Student Affairs in Africa. She serves on the Governing Board of the Consortium of Higher Education Researchers (CHER). 